Original Research Paper

\title{
Pharmacological Properties of Bioactive Extracts from the Rhizome of Aristolochia longa $\mathrm{L}$
}

\author{
${ }^{1 *}$ Amal El Hamsas El Youbi and ${ }^{2}$ Dalila Bousta \\ ${ }^{I}$ Laboratory of Biology and Health, Faculty of Sciences Ben M'Sik, Hassan II-Casablanca University, Casablanca, Morocco \\ ${ }^{2}$ Laboratory of Neuroendocrinology and Nutritionnel and Climatic Environment, University of Sidi Mohamed Ben Abdellah, \\ FSDM-Fez, Morocco
}

\author{
Article history \\ Received: 08-01-2020 \\ Revised: 03-06-2020 \\ Accepted: 20-07-2020 \\ Corresponding Author: \\ Amal El Hamsas El Youbi \\ Laboratory of Biology and \\ Health, Faculty of Sciences \\ Ben M'Sik, Hassan II- \\ Casablanca University, \\ Casablanca, Morocco \\ Email: amal.elyoubi@gmail.com
}

\begin{abstract}
Aristolochia longa is a medicinal plant well known in Moroccan folk medicine for its activity against constipation, intestinal infections and skin diseases. The present study was performed to evaluate in vitro and in vivo immunomodulatory and cytotoxic activities of aqueous and protein extracts of A. longa. The in vitro immunomodulatory results showed that aqueous extract at $0.1 \mathrm{mg} / \mathrm{mL}$ enhanced T-lymphocyte cells proliferation in the presence of ConA. While, in the presence of ConA and PMA, the protein extract at 0.1 $\mathrm{mg} / \mathrm{mL}$ induced a significant decrease of T-lymphocytes and splenocytes proliferation. Both extracts were found to exhibit a significant diminution in phagocytic capacity and macrophage cells proliferation. They also induced a significant decline in the non-specific and specific humoral immune response. The protein chromatography separation was used to isolate two major fractions (F1: 75KDa and F2: $5 \mathrm{KDa}$ ) which showed an inhibitory effect on all studied immune cells. The in vivo immunomodulatory response of aqueous and protein extracts have equally evoked a significant dose dependent suppressor effect on total leukocyte count including the lymphocytes, monocytes and granulocytes, whereas the LD50 was $1.26 \mathrm{~g} / \mathrm{kg}$ by intraperitoneal route. A. longa extracts also demonstrated apoptotic effects by about 9 to $11 \%$ against normal immune cells which confirmed the cytotoxic effects of both extracts. In conclusion, Aristolochia longa extracts exerts immunosuppression activities in vitro and in vivo, have cytotoxic effects in vivo explained by the apoptotic properties of aqueous and protein extracts against normal immune.
\end{abstract}

Keywords: Aristolochia longa, Immunomodulatory Properties, Cytotoxic Activity, Toxicity, Apoptotic Assay

\section{Introduction}

For long time, the natural products have been used as the main source of therapies; about $25 \%$ of the drugs prescribed world wide are from plants. This interest is due to several reasons, namely, conventional medicine can be inefficient, abusive and nevertheless, the folk medicine and ecological awareness suggest that natural products are harmless. Many medicinal plants' actions may be mediated by interaction with the immune system.

The genus Aristolochia consists of about 400 species across tropical Asia, Africa and South America. Some species of Aristolochia have been cultivated to be used in folk medicine and as ornamentals (Duke, 1985).

It was reported that species of Aristolochia exhibits numerous biological effects, antiviral, antibacterial, antispasmodic (Wu et al., 2004).
In Morocco, species Aristolochia longa $L$. (paucinervis Pomel) is used in traditional medicine to treat cancer diseases, skin infections (Charnot, 1954; Bellakhdar, 1997; Merzouki et al., 1997) and respiratory infections by enhancing immunity defense (Bellakhdar, 1997; Merzouki et al., 1997; Gadhi et al., 1999). In addition, the ingestion of little amount of a mixture of $A$. longa Pomel rhizome powder with either honey or salted butter is used by several traditional healers for the treatment of abdominal pains and infections of the upper respiratory tract (Bellakhdar, 1997; Belkhadar et al., 1991; Benchaâbane and Abbad, 1997). However, some scientific work was interested in Aristolochia longa in which authors described the antibacterial action of rhizome plant extract (Gadhi et al., 1999; 2001a; 2001b).

The authors in this study intends to study the effects of bioactive extracts from the rhizome of Aristolochia longa 
(AL) on in vitro and in vivo immunological responses including modulation, cytotoxic and apoptotic properties.

\section{Materials and Methods}

\section{Chemical Materials and Preparation}

All chemicals' products used in this study were purchased from Sigma (St Louis, MO, USA).

\section{Animals}

The bred Zemmouri male rabbits weighing $2.5 \mathrm{Kg}$ were used for in vitro investigations, whereas the Male Swiss albino mice $(30 \pm 2 \mathrm{~g})$ were used for in vivo experiments. These animals were given synthetic pellet diet and clean tap water ad libitum and maintained at $24 \pm 1^{\circ} \mathrm{C}$ with $55 \pm 5 \%$ relative humidity and day and night cycles of $12 \mathrm{~h}$ each. They were approved by the Universal Animal Experimental Ethics Committee.

\section{Plants Material}

Aristolochia longa rhizome was collected from the Boulmane region in Morocco. The plant's specimen was identified and a voucher specimen was deposited in the Laboratory of Bioactive Molecules (LMBSF), FST of FEZ under the number $n^{\circ} 005 / 2006$.

\section{Method of Extraction}

Ten grams of the powder was dissolved in $100 \mathrm{~mL}$ of Phosphate Buffer Saline (PBS, $150 \mathrm{mM}, \mathrm{pH}$ 7.4) with stirring during $2 \mathrm{~h}$. The suspension was centrifuged (15 min at $2700 \mathrm{~g} 4^{\circ} \mathrm{C}$ ) and the supernatant sterilized by filtration through $0.22 \mu \mathrm{m}$ nitrocellulose filters. The concentration of the extracts tested in this study is $0.1 \mathrm{mg} / \mathrm{mL}$. Protein extract was then obtained by $40 \%$ (w/v) ammonium sulphate precipitation (Englard and Seifter, 1990).

\section{Sephadex-Chromatography Column}

Protein extract was separated on sephadex (G-100) chromatography column $(40 \times 2 \mathrm{~cm}, \mathrm{~W}$, Facher bround). Elution was performed by PBS at a rate of $120 \mathrm{~mL}$ per $\mathrm{h}$. Fractions of $2 \mathrm{~mL}$ were collected and their protein concentration determinated by measuring absorbance at $280 \mathrm{~nm}$.

\section{Acute Toxicity Study}

LD50 value of aqueous extract of A. longa was determined in male Swiss mice $(30 \pm 2 \mathrm{~g})$ through intraperitoneal route $\nleftarrow$ i. $p *$ according to the method of (Miller and Tainter, 1944). Swiss mice are treated by different doses of aqueous extract $(40,80,170,340,630$, $852,1270,1790$ and $2130 \mathrm{mg} / \mathrm{kg}$, i.p.) and mortality was recorded up to $24 \mathrm{~h}$ of observation. Seven mice were taken in each dose level.
In vitro and in vivo Immunomodulation Investigations

In vitro Immunomodulation Activities

\section{Cells, Materials and Culture}

Cells suspension used in this study were obtained from rabbit. Briefly, animals were sacrificed under anesthesia and spleens and thymus were removed aseptically and suspensions prepared by pressing the organs through a fine wire mesh. Cell suspensions were washed by centrifugation repeated in RPMI and the red blood cells were lysed by $154 \mathrm{mM}$ Ammonium Chloride. The number of viable cells was determined microscopically by trypan blue exclusion test.

The culture used RPMI medium (without glucose) supplemented with $2 \mathrm{mM}$ glutamine, $1 \mathrm{mM}$ sodium pyruvate, $10 \%$ (v/v) FCS (fetal calf serum) and antibiotics (ampicillin $100 \mathrm{U} / \mathrm{mL}$ and streptomycin $100 \mathrm{mg} / \mathrm{mL}$ ).

\section{Phagocytosis Cells}

The phagocyte test was performed as described before by (EL Hamsas EL Youbi et al., 2010). Briefly, macrophages were obtained from spleen cell preparation (see before). $100 \mu \mathrm{L}$ of spleen cell suspension at $10^{6}$ cells $/ \mathrm{mL}$ was added in 96 well plates that were incubated at $37^{\circ} \mathrm{C}$ during $3 \mathrm{~h}$ for adherence of macrophages. Thereafter, supernatant was removed and every wellplates was washed twice with sterile PBS.

The phagocyte test was conducted using neutral red as indicator of phagocytic action of macrophages. In every well-plate, $100 \mu \mathrm{L}$ of RPMI (with $10 \%$ (v/v) FCS) containing $0.075 \%$ of neutral red and $10 \mu \mathrm{L}$ of plant extracts (or PBS in the blank) were added and then plates incubated for $2 \mathrm{~h}$. Finally, after removing supernatant and three times washing, reaction was stopped with a solution containing acetic acid $(1 \mathrm{M}) /$ ethanol $(1: 1 \mathrm{v} / \mathrm{v})$. Phagocytosis was evaluated by measuring absorbance at $540 \mathrm{~nm}$.

Proliferation of adherent macrophages was measured as described above using colorimetric MTT test.

\section{Cell Proliferation Assay}

Proliferation of cells (splenocytes, thymocytes and macrophages) was performed as described by (Daoudi et al., 2008) and was measured through using MTT assay (Mosdam, 1983). Briefly, cell suspensions were plated at 5000 cells/well in 96 well plates and incubated at $37^{\circ} \mathrm{C}$ in humidified chamber under an atmosphere of $95 \%$ air and $5 \% \mathrm{CO}_{2}$ for $72 \mathrm{~h}$. Plant extracts was added to cells before their incubation at the concentration of $0.1 \mathrm{mg} / \mathrm{mL}$ for aqueous extract, protein extract and their fractions.

Thereafter, $10 \mu \mathrm{L}$ of MTT solution $(5 \mathrm{mg} / \mathrm{mL}$ in PBS) was added. After three $\mathrm{h}$ of incubation, the supernatant was removed and replaced by $100 \mathrm{~mL}$ of DMSO. Finally, the optical density was measured through wavelength at $570 \mathrm{~nm}$. 


\section{Plaque-Forming Cell Assay}

The PFC assay was performed using the method of (Cunningham, 1965) with some modification as notified by (EL Hamsas EL Youbi et al., 2010). Rabbits were previously immunized with mice red blood "(MRB)". The spleen was removed, cleaned free of extraneous tissues and a single cell suspension of $10^{6}$ cells $/ \mathrm{mL}$ was prepared from it in RPMI medium. For PFC assay, the MRB was prepared at a cell density of $5 \times 108$ cells $/ \mathrm{mL}$ in $\mathrm{NaCl} 0.9 \%$. One milliliter of MRB in medium was added to $1 \mathrm{~mL}$ of spleen cell suspension with or without $A$. longa extracts and then introduced in Cuningham chambers. The chambers were sealed with paraffin and incubated at $37^{\circ} \mathrm{C}$ for $2 \mathrm{~h}$. The PFC were counted under a light microscope and expressed as PFC per 106 spleen cells (Raisuddin et al., 1991).

\section{Allogenic Mixed Lymphocyte Reaction (MLR)}

Thymus from rabbits was aseptically removed and placed in complete RPMI medium. Thymocytes were then obtained as described for splenocytes. Red Blood Cells (CRBC) were obtained from chicken and were washed by $\mathrm{NaCl} 0.9 \%$ before use. For MLR assay, the CRBC were prepared at a cell density of $5.10^{5}$ cells $/ \mathrm{mL}$ in PBS. $50 \mu \mathrm{L}$ of CRBC in medium was added to one milliliter of thymocytes $\left(1 \times 10^{6}\right.$ cells $\left./ \mathrm{mL}\right)$ flowed by the addition of $100 \mu \mathrm{L} /$ well in 96-well- culture plates as a final volume. Cell mixture was then incubated in presence or absence of A. longa extracts, for $24 \mathrm{~h}$ at $37^{\circ} \mathrm{C}$ in humidified atmosphere. Cytotoxicity of thymocytes against CRBC was evaluated by measuring the liberation of CRBC hemoglobin in the medium by determining the absorbance at $640 \mathrm{~nm}$.

\section{Complement Test}

The effect of $A$. longa extracts on complement production is based on inhibition or activation of haemolysis of Mouse Red Blood Cells (MRBC) by the complement pathway in the presence of anti-MRBC antibodies prepared in immunized rabbits. Firstly, MRBC were washed twice with $\mathrm{NaCl} 0.9 \%$ and a $1 \%$ cell suspension was prepared. MRBC (suspension at $0.5 \%$ ) was diluted in $\mathrm{NaCl} 0.9 \%$ and then the complement and serum containing anti-MRBC antibodies were added. MRBC were next incubated on a 96 well plate in the presence or absence of A. longa extracts at $37^{\circ} \mathrm{C}$ during $90 \mathrm{~min}$. After incubation, $100 \mu \mathrm{L}$ of the supernatants were transferred to a new plate and the absorbance at 540 $\mathrm{nm}$ measured using a micro-plate reader.

\section{In vivo Immunomodulation Activity}

To assay the stage of in vivo immunomodulatory activity was done as described previously by (EL Hamsas EL Youbi et al., 2011). Twenty-four h after treatment with the aqueous (80 and $170 \mathrm{mg} / \mathrm{kg} / 24 \mathrm{~h}$ ) and protein (3 and $6 \mathrm{mg} / \mathrm{kg} / 24 \mathrm{~h}$ ) extracts of $A$. longa, animals were anesthetized, the blood was collected in heparinized tubes and erythrocytes were lysed by the addition of ammonium chloride. Then, the peripheral leukocytes were suspended in tampon isotone. Immunomodulatory activities of $A$. longa extracts were measured in a flow cytometer (Epics-XL MC laser cytometer). These analyses are based on different immune cells morphology (structure and size).

\section{Apoptosis Activity Study}

In vivo apoptosis assay of normal immune cells was performed following the method of (EL Hamsas EL Youbi et al., 2012). Twenty-four h after treatment with the aqueous and protein extracts of $A$. longa, animals were anesthetized, the blood was collected in heparinized tubes and erythrocytes were lysed by the addition of ammonium chloride. Then, the peripheral leukocytes were suspended in annexin-binding buffer and centrifuged twice. The pellets were resuspended in the same buffer $(100 \mathrm{~mL})$ containing annexin-V FITC and propidium iodide. After $15 \mathrm{~min}$ of incubation in dark at room temperature analysis was done by flow cytometer (Epics-XL MC laser cytometer). Flowcytometric reading was taken using $488 \mathrm{~nm}$ excitation and band pass filters of $530 / 30 \mathrm{~nm}$ (for FITC detection) and 585/42 nm (for PI detection).

\section{Statistical Analysis}

Each experimental condition was realized at least in triplicate $(\mathrm{n}=3)$. Data were expressed as the mean \pm Standard Deviation (S.D.). Statistical analyses were carried out using the student's t test. Differences were considered statistically significant at $p<0.05$.

\section{Results}

\section{Acute Toxicity Studies}

LD50 value of aqueous extract was found to be $1.26 \mathrm{~g} / \mathrm{kg}$, i.p. in male Swiss mice. However, any signs of toxicity were observed at doses lower than $1.26 \mathrm{~g} / \mathrm{kg}$ (Fig. 1).

\section{In vitro Immunomodulatory Activities}

\section{Effects of A. Longa Extracts on Cellular Immune Function}

The effects of AL extracts on cellular immune function were estimated by measuring lymphocyte and splenocyte proliferations in vitro (Fig. $2 \mathrm{a}$ and $2 \mathrm{~b}$ ). In the assay, spleen lymphocyte proliferation activity was significantly increased in aqueous extract treatment $(p<0.05)$, but no effect was observed on thymocyte proliferation. However, in the presence of the Aqueous Extract (AE), mitogenic agents exercised a stimulatory effect in both types cellular; Thymocyte + Con-A $=55 \%$, $p<0.01$ and splenocyte + PMA $=20 \%$ compared with 
control. Indeed, the Protein Extract (PE) at $0.1 \mathrm{mg} / \mathrm{mL}$ stimulated thymocyte and spleen lymphocytes proliferation. When mitogens were added to protein extracts, we observed a total inhibition of mitogenic action of Con-A and PMA on splenocytes and thymocytes respectively Thymocyte + Con-A $=56 \%$ and splenocyte + PMA $=38 \%$ compared with control (Fig. 2a and 2b).

\section{Effect of Protein Fractions}

Aristolochia longa protein extract has been fractioned on G100 sephadex column (Fig. 3). The chromatography profile obtained shows presence of two major fractions F1 (76 KDa) and F2 (5 KDa) (Fig. 3). The F1 and F2 fractions have been tested on proliferation of splenocytes and thymocytes. Results obtained indicate that F1 and F2 stimulated thymocytes proliferation $(\mathrm{F} 1=161 \% ; \mathrm{F} 2=$ $102 \%$ of control response) when they do not modify significantly proliferation of splenocytes ( $\mathrm{F} 1=10 \%$; F2 $=27 \%$ of control response) (Fig. 4).
On thymocytes, in the presence of Con-A (Fig. 4a), F2 inhibits cell proliferation but F1 is without effect since we record a stimulation of thymocytes by Con-A. On splenocytes, in the presence of PMA, F1 and F2 block the induced cells proliferation (Fig. 4b).

\section{Effects of AL Extract on Phagocytosis}

The effects of AL extracts on nonspecific immune function were estimated by measuring the phagocytic activity and proliferation of phagocytic cells. The addition of AL extracts or protein fractions to phagocytic cells leads to a reduction of their activity as compared to the control (Fig. 5a). These inhibitions were correlated to a diminution of macrophage viability as shown in Fig. 5b. Therefore, the addition of aqueous extract, protein extract and their fractions (F1 and F2) induce respectively a reduction in cell number by $64 \%$ for $\mathrm{AE}$, $62 \%$ for $\mathrm{PE}, 73 \%$ for $\mathrm{F} 1$ and $70 \%$ for $\mathrm{F} 2$.

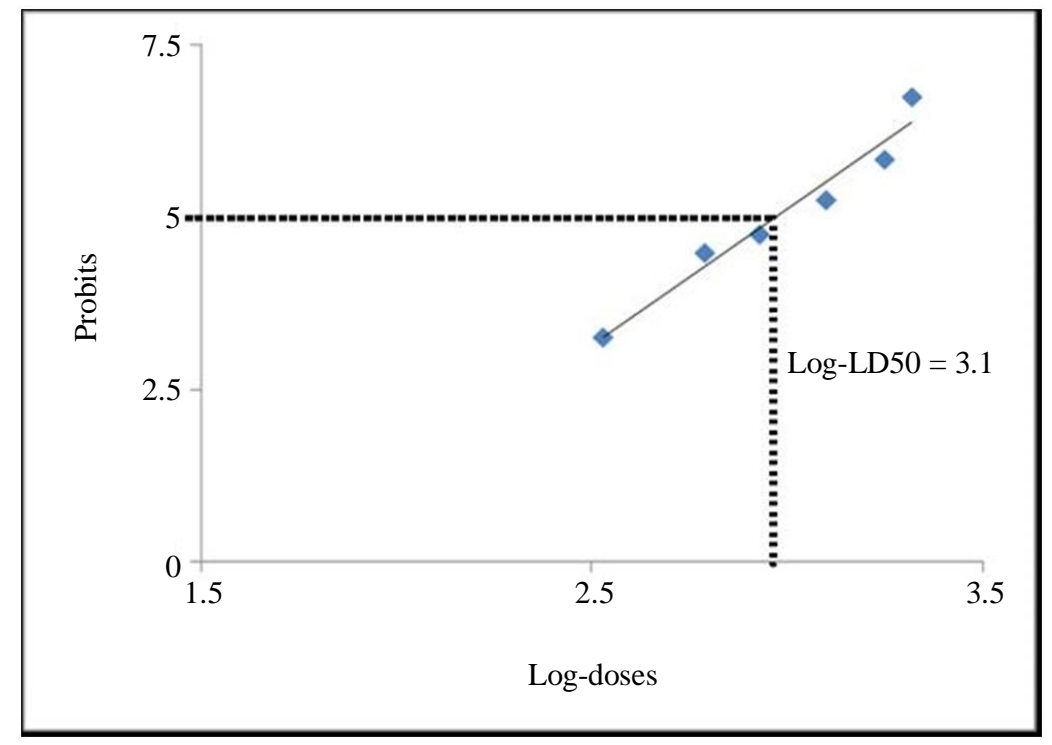

Fig. 1: Plot of log-doses versus profits for calculation of LD50 of A. longa administered by intraperitoneal route

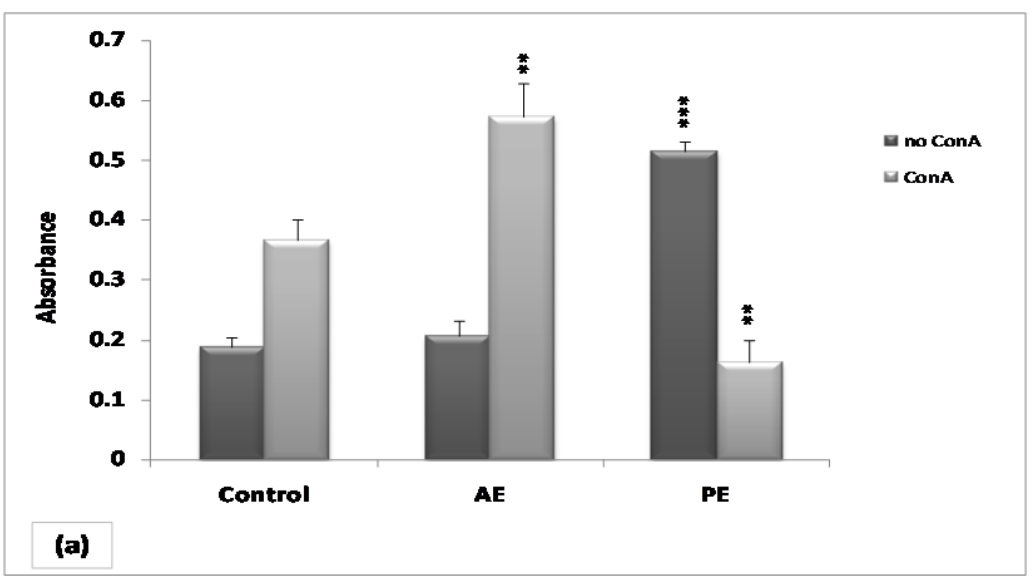




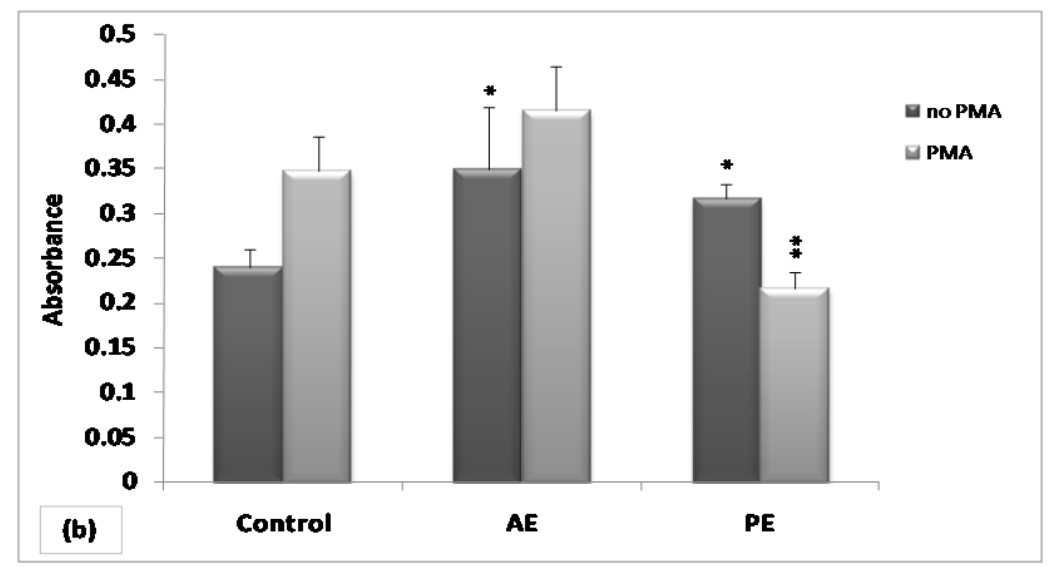

Fig. 2: Effects of A. longa aqueous and proteins extracts on thymocytes proliferations (a), on splenocytes proliferations (b). AE: Aqueous extract at $0.1 \mathrm{mg} / \mathrm{mL}$, PE: Protein extract at $0.1 \mathrm{mg} / \mathrm{mL}$. Values represent the mean $\pm \mathrm{S} . \mathrm{D}$ of five animals. ${ }^{*} \mathrm{p}<0.05$, $* * \mathrm{p}<0.01, * * * \mathrm{p}<0.001$ when compared with the control (significantly different).

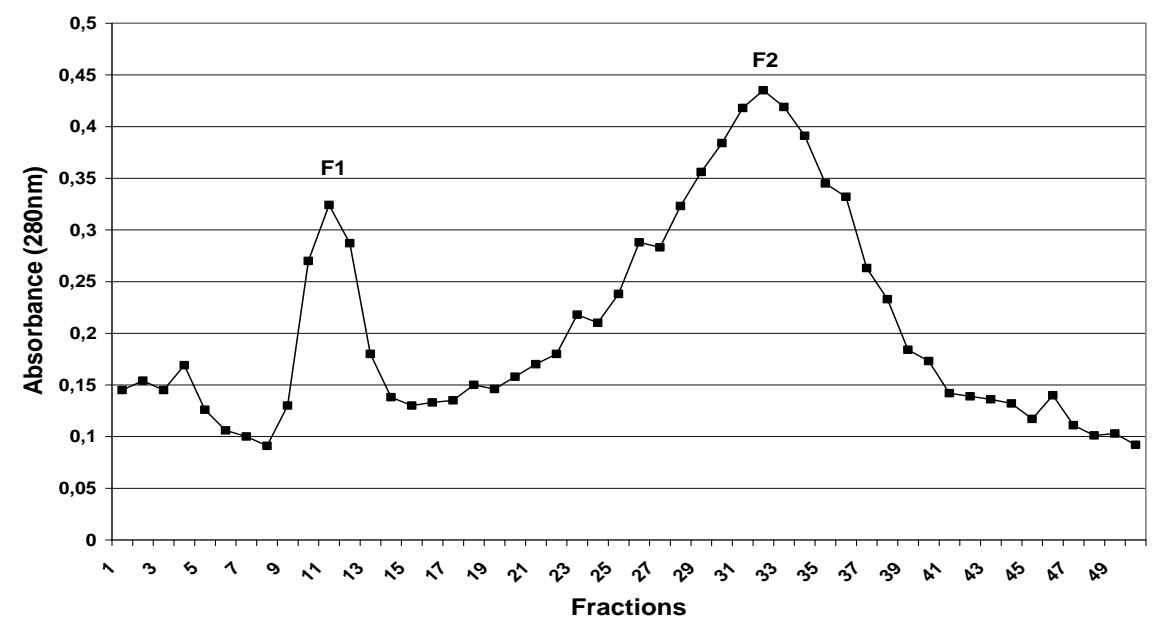

Fig. 3: Chromatography profile of A. longa protein separation on G100 sephadex column.

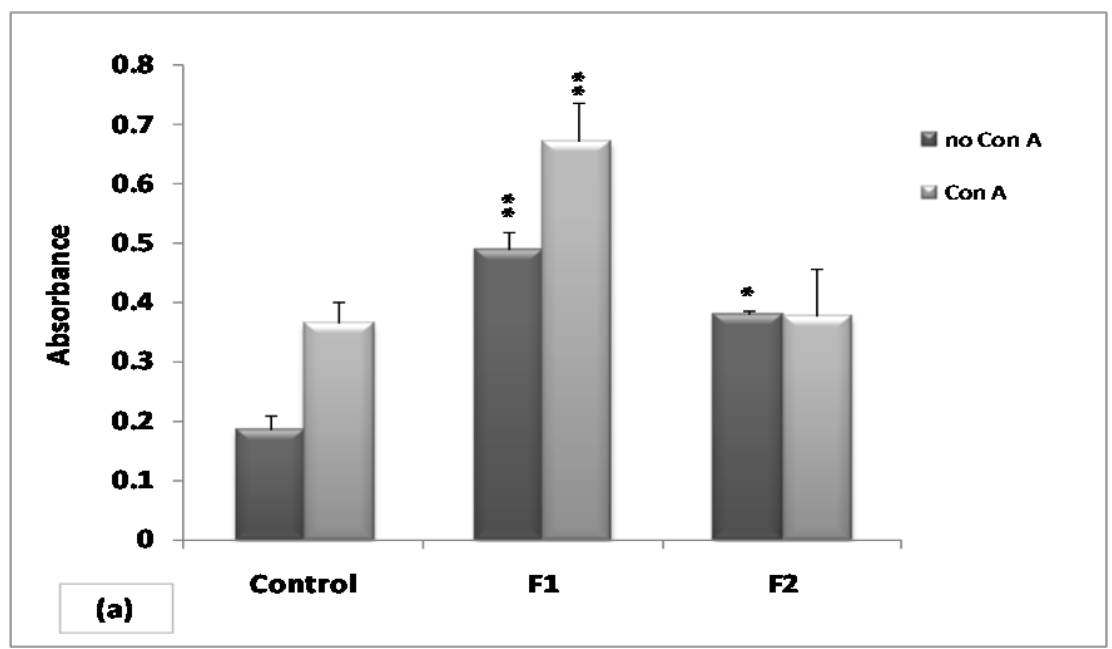




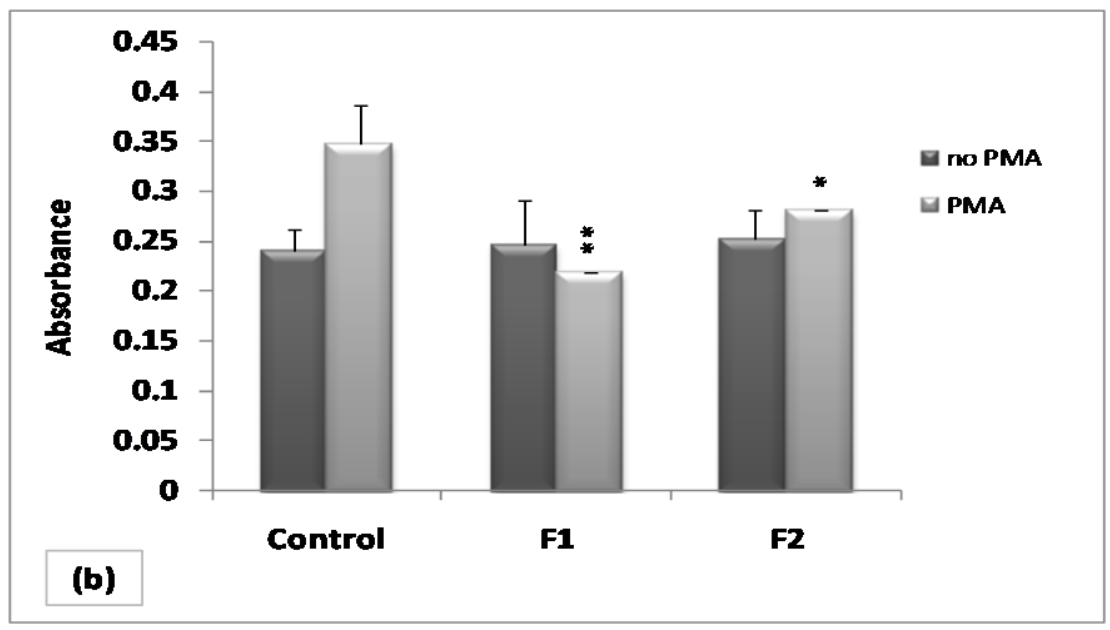

Fig. 4: Effects of proteins fractions the A. longa on thymocytes proliferations (a), on splenocytes proliferations (b). Fractions proteins [F1: $0.07 \mathrm{mg} / \mathrm{mL} ; \mathrm{F} 2: 0.1 \mathrm{mg} / \mathrm{mL}$ ]. Values represent the mean \pm S.D of five animals. $* \mathrm{p}<0.05$, **p $<0.01$ when compared with the control (significantly different).
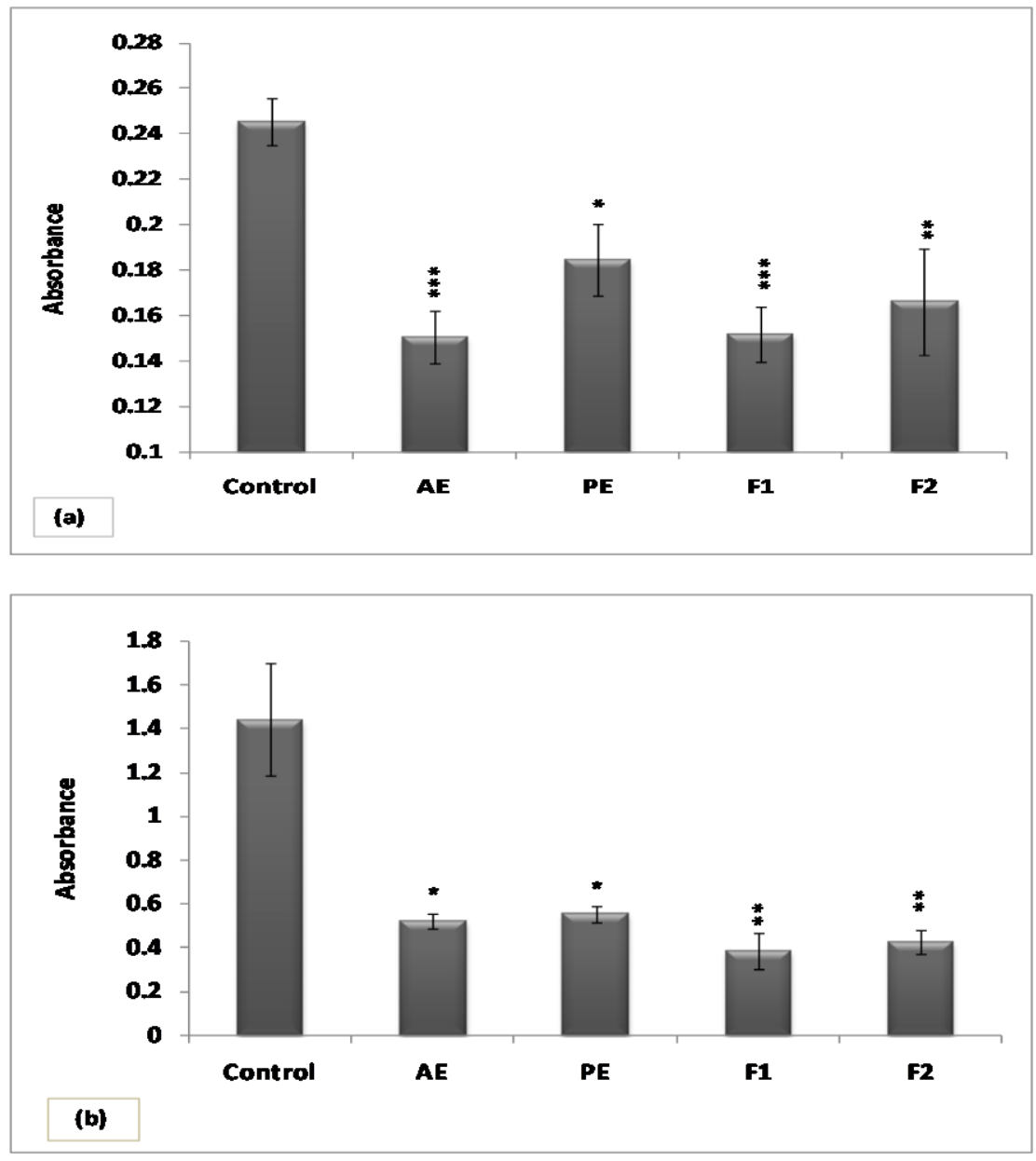

Fig. 5: Effects of $A$. longa of macrophage assessed by Neutral red assay (a), on macrophage proliferation assessed by MTT assay (b). $\mathrm{AE}$ : Aqueous extract at $0.1 \mathrm{mg} / \mathrm{mL}, \mathrm{PE}$ : Protein extract at $0.1 \mathrm{mg} / \mathrm{mL}$ and fractions proteins [F1: $0.07 \mathrm{mg} / \mathrm{mL} ; \mathrm{F} 2: 0.1$ $\mathrm{mg} / \mathrm{mL}]$. Values represent the mean \pm S.D of five animals. ${ }^{*} \mathrm{p}<0.05, * * \mathrm{p}<0.01, * * * \mathrm{p}<0.001$ when compared with the control (significantly different). 


\section{Effects of A. Longa Extract on Humoral Immune} Function

The effects of AL extract on humoral immune function were estimated by PFC assay and by evaluation of complement activity. As shown in Fig. 6, a significant reduction in the PFC was observed in presence of $\mathrm{AE}$ (98\% of control) and PE ( $76 \%$ of control). The effect of aqueous extract at $0.1 \mathrm{mg} / \mathrm{mL}$ is more pronounced than that of protein extract at $0.1 \mathrm{mg} / \mathrm{mL}$.

Results of complement assay are shown in Fig. 7. Only the protein extract shows a significant reduction of complement activity. PE induced a response of $27 \%$ compared to $\mathrm{AE}$ with $15 \%$ versus control.

\section{Effect of A. Longa on Allogenic Mixed Lymphocyte Reaction}

The immune-potency of aqueous and protein extracts of A. longa on lymphocyte $\mathrm{T}$ cytoxicity was assessed using MLR test. The result illustrated by Figure 8 shows that the aqueous and protein extracts have an opposite effect, $\mathrm{AE}$ at $0.1 \mathrm{mg} / \mathrm{mL}$ increase highly MLR activity (170\% of response of Control), whereas the protein extract decreases this activity and we record only $40 \%$ of response.

\section{In vivo Immunomodulatory Activity}

The effects of A. longa extracts on total leukocyte count were investigated by flow cytometer analysis. As shown in Fig. 9a, significant suppressor effects were observed after administration of aqueous extract at 80 and $170 \mathrm{mg} / \mathrm{kg}$ on lymphocyte, monocyte and granulocyte cells percentages compared to group control. While, the protein extract at 3 and $6 \mathrm{mg} / \mathrm{kg}$ showed an enhancing suppressor activity on different leukocyte cells. However, this activity was much stronger (significant) than aqueous extract effects specifically on thymocyte cells (Fig. 9a and 9b).

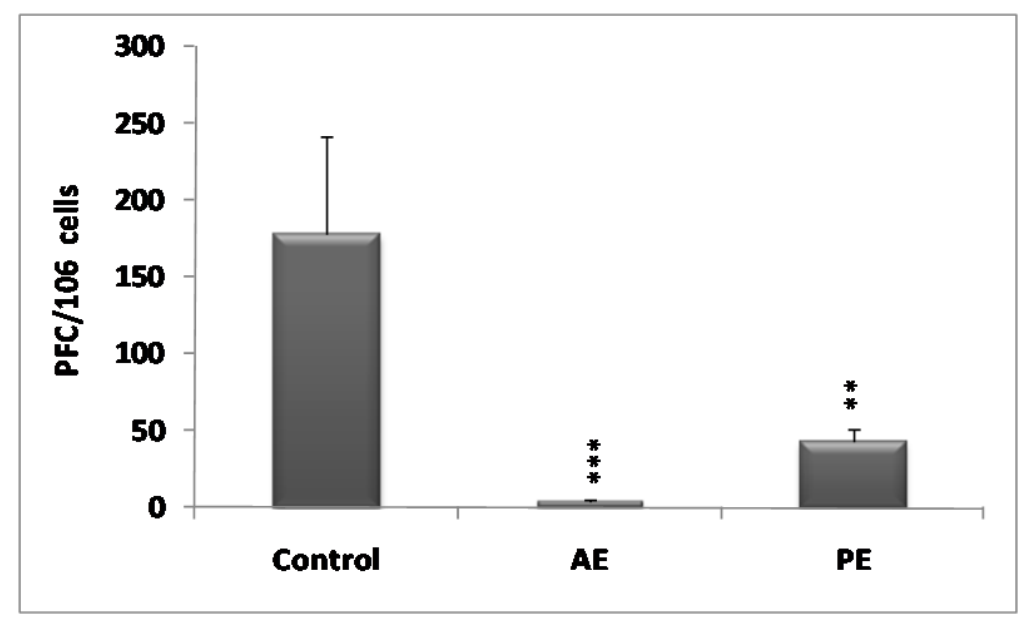

Fig. 6: Effects of A. longa extracts on the humoral immunity as assessed by the plaque-forming cell assay. AE: Aqueous extract at $0.1 \mathrm{mg} / \mathrm{mL}$, PE: Protein extract at $0.1 \mathrm{mg} / \mathrm{mL}$. Values represent the mean \pm S.D of five animals. $* * \mathrm{p}<0.01, * * * \mathrm{p}<0.001 \mathrm{when}$ compared with the control (significantly different).

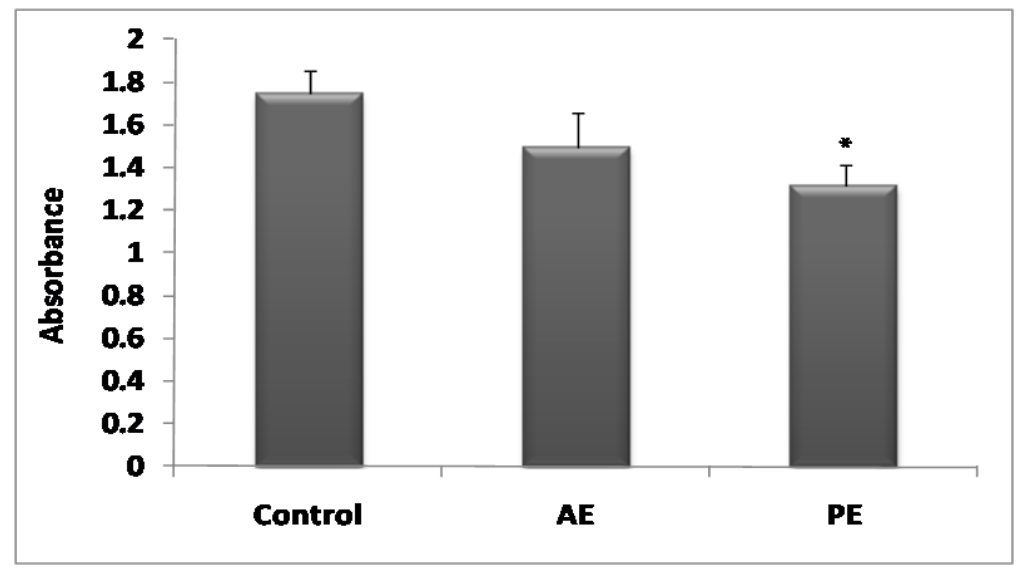

Fig. 7: Effects of A. longa extracts on complement secretion. AE: Aqueous extract at $0.1 \mathrm{mg} / \mathrm{mL}$, PE: Protein extract at $0.1 \mathrm{mg} / \mathrm{mL}$. Values represent the mean \pm S.D of five animals. ${ }^{*} p<0.05$, when compared with the control (significantly different). 


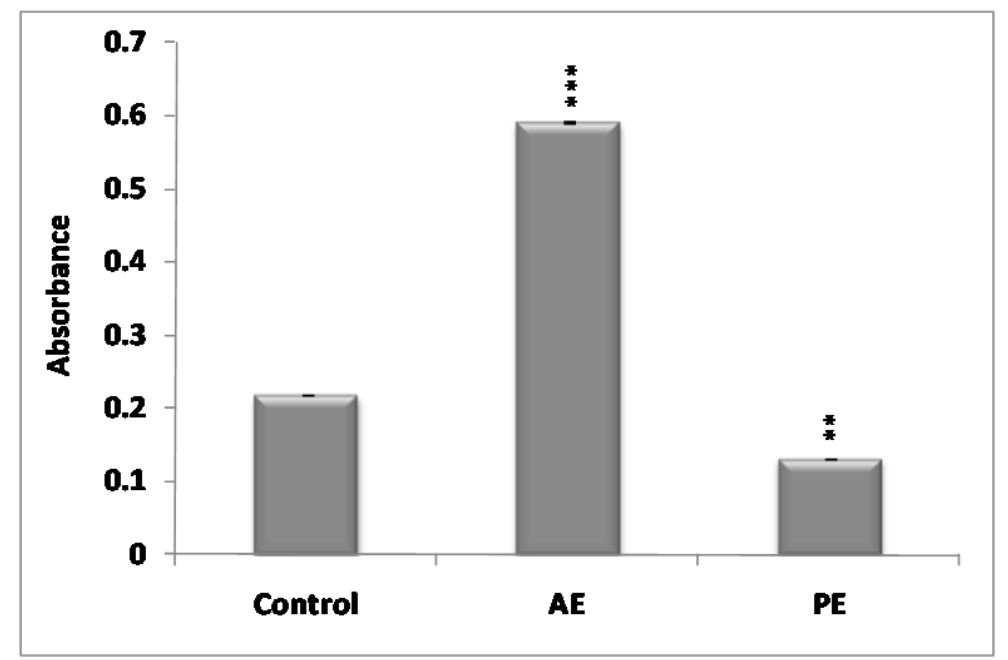

Fig. 8: Effects of A. longa extracts on Allogenic mixed lymphocyte reaction. AE: Aqueous extract at $0.1 \mathrm{mg} / \mathrm{mL}, \mathrm{PE}$ : Protein extract at $0.1 \mathrm{mg} / \mathrm{mL}$. Values represent the mean \pm S.D of five animals. $* * p<0.01, * * * p<0.001$ when compared with the control (significantly different).
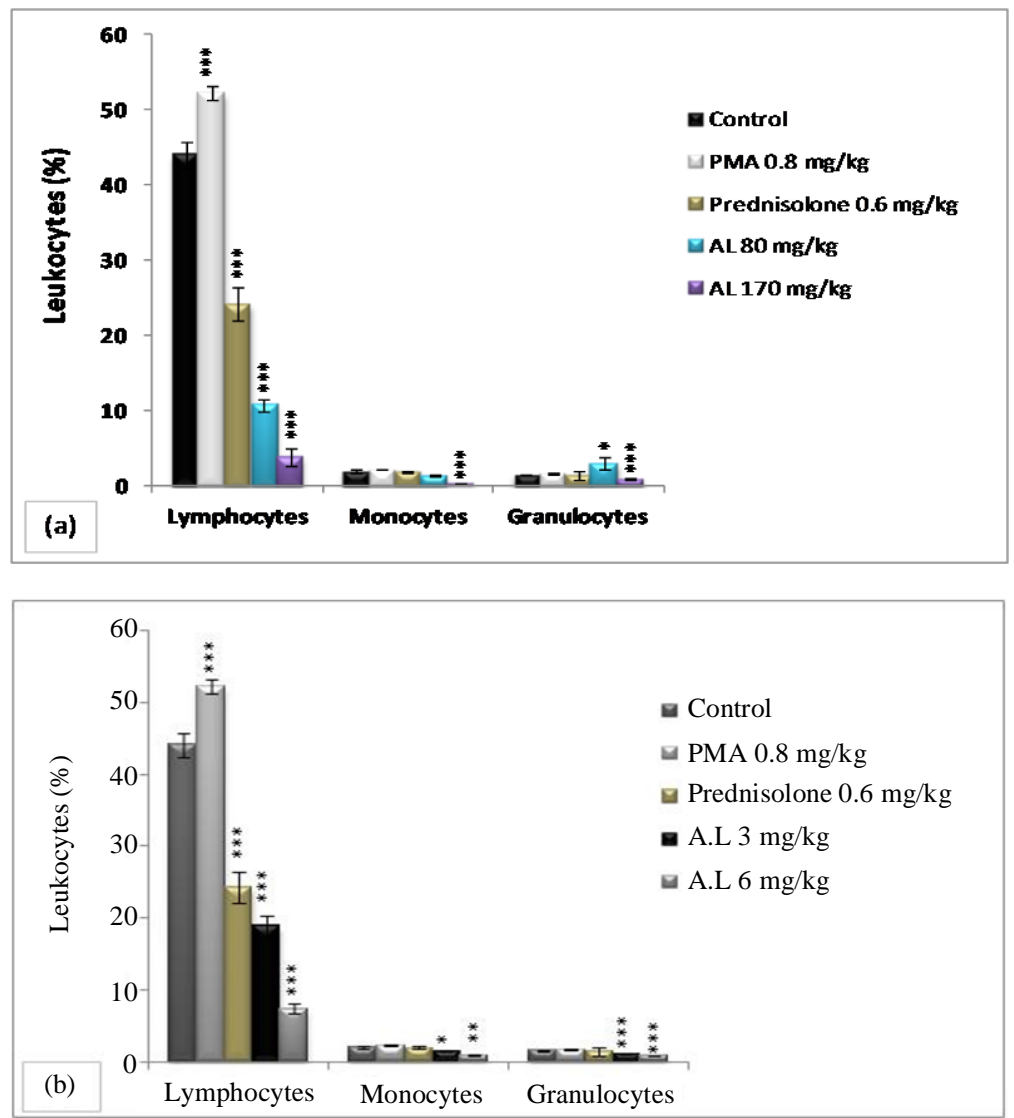

Fig. 9: Effects of A. longa aqueous extract on Total leukocyte percentage (a). Effects of $A$. longa protein extract on Total leukocyte percentage (b). Values represent the mean \pm SEM; $n=6$ of every groups. $* \mathrm{p}<0.05, \mathrm{p} * *<0.01, * * * \mathrm{p}<0.001$

\section{Apoptotic Activity}

The four different quadrants of flow-cytometric data represent four different states of cells. The Lower Left (LL),
annexin-/PI- represents normal healthy cells. The Lower Right (LR), annexin+/PI- and Upper Right (UR), annexin+/PI+ quadrant represent early and late apoptotic cells, respectively and the Upper Left quadrant (UL), 
annexin-/PI+ represents only necrotic cells. $\mathrm{AE}$ at 80 $\mathrm{mg} / \mathrm{kg}$ and $\mathrm{PE}$ at $3 \mathrm{mg} / \mathrm{kg}$ treatment of cells produced $6.5 \pm 0.2 \%$ and $9 \pm 0.1 \%$ cells, respectively, in LR quadrant and $0.5 \pm 0.01 \%$ and $8 \pm 0.4 \%$ cells, respectively, in UR quadrant as compared to $11 \pm 0.1 \%$ cells in LR quadrant and $1 \pm 0.04 \%$ cells in UR quadrant of control cells treated by Butyric acid at 5 $\mathrm{mg} / \mathrm{kg}$ (Fig. 10 and 11).

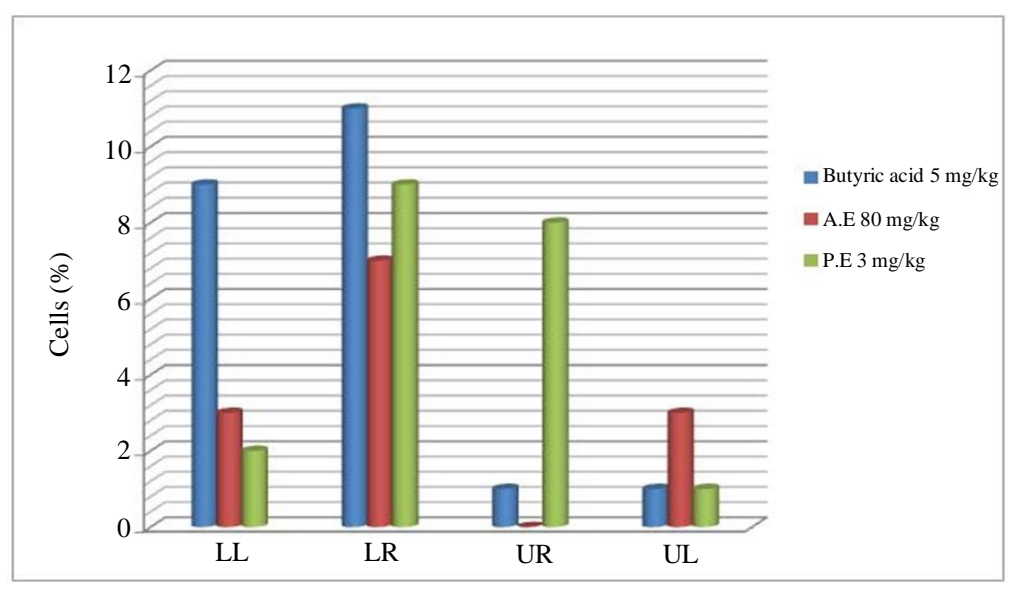

Fig. 10: Effects of Aqueous and protein extracts of A. longa on apoptosis leukocyte cells, detected by a co-branding to AnnexinFITC/IP. The values represent the percentages in cellular phases of apoptosis and necrosis. LL: Live cells, LR: Early apoptotic cells, UR: Late apoptotic cells, UL: Necrosis cells

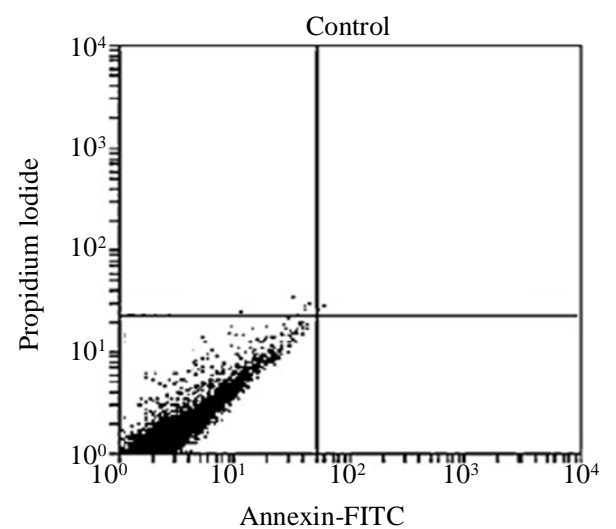

(a)

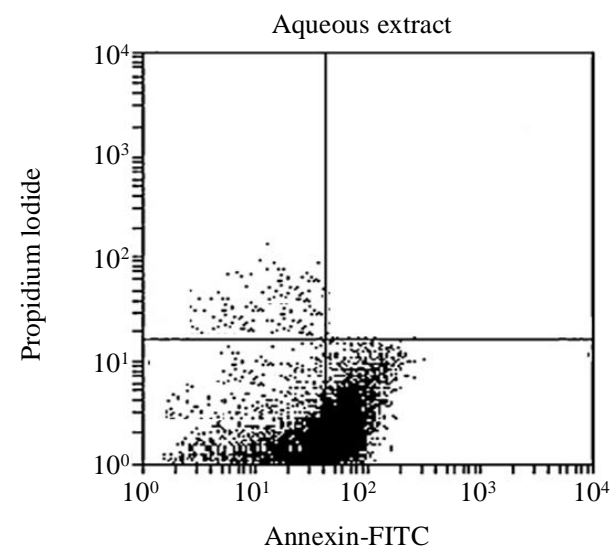

(c)

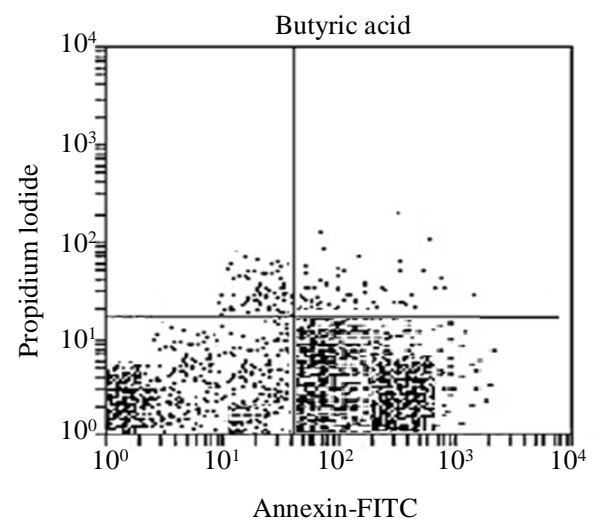

(b)

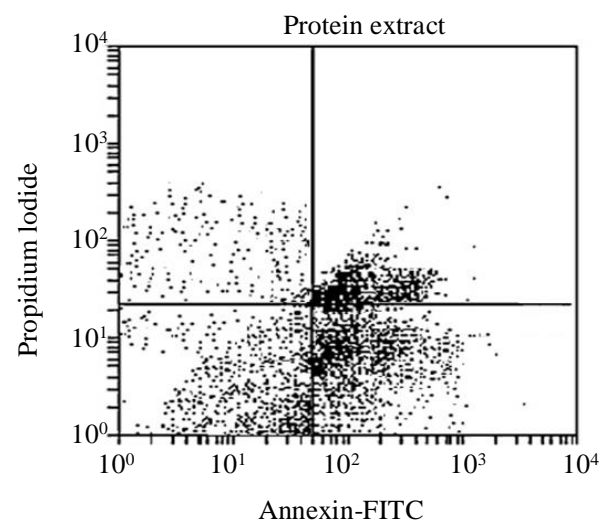

(d)

Fig. 11: Effects of aqueous extract of A. longa (c) and protein extract (d) on the leukocyte cell apoptosis, detected by a co-branding with Annexin-FITC/IP compared with group treated by butyric acid (b) and a group treated by $0.9 \% \mathrm{NaCl}$ (a). The histograms show four different states of cells. LL: Live cells, LR: Early apoptotic cells, UR: Late apoptotic cells, UL: Necrosis cells 


\section{Discussion}

Immunomodulation may be specific and limited to antigen/agent or non-specific, with a general effect on immune response. Suppression of the immune response is desired for certain cases such as in organ transplantation, allergic and inflammatory disease patients, whereas potentiating of the immune response is needed for others, such as for immunocompromised. The evaluation of plants and/or products that either promote or inhibit immunocyte proliferation is crucial to the study of immunomodulation and drug discovery (Yadav et al., 2011; Ngoupayo et al., 2009; Liu et al., 2010). While, this study needs a toxicological investigation to provide security of natural products in future clinical studies. In this report, we first evaluated the in vivo toxic effects of $A$. longa aqueous extract by the acute toxicity test according to the (Miller and Tainter, 1944). The results showed that the LD50 for aqueous extract was $\geq 1.26 \mathrm{~g} / \mathrm{kg}$ i.p. However, the same species showed a LD50 of $2.5 \mathrm{~g} / \mathrm{kg}$ o.p in Swiss albino mice (Benzakour et al., 2011). The results regarding the toxicological effects of $A$. longa aqueous extract evaluated in vivo suggest that this plant might be considered as low toxic after administration by i.p route without considering the adverse effects of Aristolochic acids the main constituent of $A$. longa. Previous research has shown that Aristolochic acids are responsible for the nephrotoxic and genotoxic effects associated with nephropathy (Lord et al., 2001; Kumar et al., 2003) after o.p administration. Then, the immunomodulatory activity of A. longa extracts was carried out by in vitro and in vivo studies. Therefore, the data of in vitro immunomodulatory effects of $A$. longa extracts demonstrated that aqueous and protein extracts of A. longa do not show any cytotoxic effect on splenocyte and thymocyte cells proliferation. Although, the protein extract increases highly proliferation of thymocyte cells where on splenocytes, both extracts induce a small increase in cells proliferation. This result indicates that extracts of $A$. longa contain a mitogenic factor responsible of the cells proliferation recorded. Hemagglutination results confirm this finding since we observe an agglutination of erythrocytes with protein extract indicating presence of a lectin (data not shown). This lectin is probably specific to thymocytes. In presence of mitogenic agents, we observe that protein extract abolish mitogenic cells proliferation of splenocyte and thymocyte cells. This data indicates that a protein of $A$. longa has an important immunosuppressive effect since they suppress specifically proliferation of these immune cells without inducing cytoxicity.

Phagocytosis represents an important immune defence mechanism in which leukocytes ingest pathogenic microorganisms, malignant cells, tissue debris and inorganic particles. The in vitro phagocytosis test was done to evaluate the effect of A. longa extracts on the phagocytic activity. A remarkable diminution in the phagocytic index was noted after adding of $A$. longa extracts. This finding might be due to a mechanism related to specific cytotoxicity compounds of $A$. longa against macrophage cells conditioned probably by potent inhibition of COX-2 activity and iNOS activity in lipopolysaccharide (Hong et al., 2002; Liu et al., 2011).

Aristolochia longa protein extract has been fractioned and two major fractions F1 (76 Kda) and F2 (5 Kda) isolated. Results indicate that F1 and F2 stimulate thymocytes proliferation without modifying proliferation of splenocytes. F2 exerts an inhibition of mitogenic cells proliferation in splenocytes and thymocytes while F1 protein fraction block only the mitogenic spleen cells proliferation. F2 seems to be the most immunosuppressive factor.

The humoral immune response is one of two main arms of the immune system; its role in generation of antibody secreting cells was studied. In PFC assay, the decrease in number of antibody secreting cells in the spleen of rabbit was clearly established by the treatment with the extracts of A. longa. Aqueous extract although produced remarkable diminution in number of antibody secreting than protein extract which indicates an alteration responsiveness of the macrophages, $\mathrm{T}$ and $\mathrm{B}$ lymphocytes subsets involved in antibody synthesis (Benacerraf, 1978) exerted principally by chemical compounds present in the aqueous extract. In non-specific humoral immune response, the treatment of $A$. longa protein extract significantly inhibited complement secretion but no significant value was obtained with aqueous extract. In view of this, it appeared that protein molecules which are responsible for a strong inhibiting of complement secretion. From these results, there is an evidence to suggest that A. longa coumpounds can be used in auto-immune disease for example: To suppress antibody production.

In a series of studies performed in our laboratory, $A$. longa aqueous extract shows an interesting effect by stimulating allogenic lymphocyte cytotoxicity without effect of protein extract. This effect is probably related to non-protein substances.

Regarding the in vivo immunomodulatory activity of $A$. longa extracts, the results proved an immunosuppressive effect of both extracts on total leukocyte count including the lymphocytes, monocytes and granulocytes in a dose dependent manner. The immunosuppressive effect of the protein extract is also most significant than aqueous extract which suggests that the bioactive molecules from the aqueous extract agonists probably the protein molecules effects. In contrast, (Benzakour et al., 2011) reported that the aqueous extract of $A$. longa administered in Swiss mice by o.p. route showed an immunostimulating effect which indicates that the effects of $A$. longa extracts are possibly related to the administration route and the metabolic pathways involved (EL Hamsas EL Youbi et al., 2010). 
Apoptosis mediated by A. longa extracts was measured by Fluorescence Activated Cell Sorter (FACS) technique. During apoptosis, the phosphatidylserine residues are translocated in the membrane and are externalised. A. longa extracts affected the phospholipid distribution over the plasma membrane of peripheral immune cells as observed by annexin-V/PI binding study. By dual staining with annexin-V FITC and propidium iodide it was possible to identify live cells, early apoptotic cells and late apoptotic cells (Darzynkiewicz et al., 2001; Wising et al., 2005). The increased number of early apoptotic cells and late apoptotic of peripheral immune cells after $A$. longa extracts treatment confirmed that both extracts exerted cytotoxic effects and induced apoptosis in immune cells. In addition, we can deduce from this finding that immunosuppressive activity of $A$. longa extracts are the result rather than the cause of apoptosis effect of these extracts. Hence, comparative study of in vitro and in vivo cytotoxic results of $A$. longa extracts did not show the same effect. This difference can be explained by the activation of cytotoxic pathways in vivo is not considered in vitro (EL Hamsas EL Youbi et al., 2010; 2011) or by in vitro diagnostic error attributed by MTT assay. Indeed, several studies have demonstrated the differences of MTT assay used for the evaluation of cytotoxicity activity (Seongeun et al., 2007).

In summary, our results demonstrate that Aristolochia longa extracts have equally showed an overall suppressor effect on humoral and cellular immune function. A successful immunosuppressive drug for protein extract and their fractions would be a breakthrough for treatment, considering that such an approach has never taken before. Thus, protein extract of A. longa could be a good source of potential immunosuppressive, anticancer drugs and could constitute an alternative extract use of A. longa further the toxicity induced by Aristolochic acids. Experiments are currently being carried out in our laboratory to isolate and evaluate active compound(s) from A. longa extracts responsible of apoptotic activity on immune cells in vivo. Future results will describe the molecular mechanism of action by which $A$. longa and its active compound(s) exert their apoptotic effects. In addition, further experiments will evaluate the capability of A. longa to suppress immune system in an in vivo model. Nevertheless, it is needed to realize more studies to elucidate the immunomodulatory mechanisms.

\section{Author's Contributions}

Amal EL Hamsas EL Youbi: Participated in all experiments, coordinated the data-analysis and contributed to the writing of the manuscript.

Dalila Bousta: Designed there search plan, organized the study and contributed in preparing the manuscript.

\section{Ethics}

This article is original and contains unpublished material. The corresponding author confirms that all of the other authors have read and approved the manuscript and no ethical issues involved.

\section{References}

Bellakhdar, J. (1997). La pharmacopée marocaine traditionnelle [Traditional Moroccan pharmacopoeia].

Belkhadar, J., Claisse, R., Fleurentin, J., \& Yaunos, C. (1991). Repertory of standard herbal drugs in the Moroccan pharmacopoeia. Journal of Ethnopharmacology, 35, 123-143.

Benacerraf, B. (1978). Opinion: a hypothesis to relate the specificity of T lymphocytes and the activity of I region-specific Ir genes in macrophages and B lymphocytes. The Journal of Immunology, 120(6), 1809-1812.

Benchaâbane, A., \& Abbad, A. (1997). Les plantes médicinales commercialisées à Marrakech. Traces du présent.

Benzakour, G., Benkirane, N., Amrani, M., \& Oudghiri, M. (2011). Immunostimulatory potential of Aristolochia longa L. induced toxicity on liver, intestine and kidney in mice. Journal of Toxicology and Environmental Health Sciences, 3(8), 214-222.

Charnot, A, (1954). La Toxicologie au Maroc. Imprimeries Réunies, pp ; 826.

Cunningham, A. J. (1965). A method of increased sensitivity for detecting single antibody-forming cells. Nature, 207(5001), 1106-1107.

Daoudi, A., Benboubker, H., Bousta, D., \& Aarab, L. (2008). Screening of fourteen, Moroccan medicinal plants for immunomodulating activities. Moroccan $\mathbf{J}$ Biol, 1, 24-30.

Darzynkiewicz, Z., Bedner, E., \& Smolewski, P. (2001, April). Flow cytometry in analysis of cell cycle and apoptosis. In Seminars in hematology (Vol. 38, No. 2, pp. 179-193). WB Saunders.

Duke, J. A, (1985). Handbook of Medicinal Herbs. Taylor and Francis, pp; 677.

EL Hamsas EL Youbi, A, Bousta, D. Jamoussi B. and Greche H. (2012). Activités antioxydante, apoptotique et antiproliférative de Tetraena gaetula (Emb. and Maire) Beier and Thulin et de Berberis hispanica Boiss. and Reut. originaires du Maroc. Phytothérap, 10 (151-160).

EL Hamsas EL Youbi, A, Bousta, D. Ouahidi I. and Aarab, L. (2010). Criblage pharmacologique primaire d'une plante endémique originaire du Sud Marocain (Tetraena gaetula [Emb. and Maire] Beier and Thulin). C R Biol, 333; (736-743). 
EL Hamsas EL Youbi, A, Bousta, D. Ouahidi I. and Aarab, L. (2011). Effets antidépresseurs, antinociceptifs et immunomodulateurs des extraits aqueux et protéique de Berberis hispanica Boiss. Reut. du Maroc. Phytothérap, 9; (25-32).

Englard, S., \& Seifter, S. (1990). [22] Precipitation techniques. In Methods in enzymology (Vol. 182, pp. 285-300). Academic Press.

Gadhi, C. A., Benharref, A., Jana, M., \& Lozniewski, A. (2001a). Anti-Helicobacter pylori activity of Aristolochia paucinervis Pomel extracts. Journal of ethnopharmacology, 75(2-3), 203-205.

Gadhi, C. A., Hatier, R., Mory, F., Marchal, L., Weber, M., Benharref, A., ... \& Lozniewski, A. (2001b). Bactericidal properties of the chloroform fraction from rhizomes of Aristolochia paucinervis Pomel. Journal of ethnopharmacology, 75(2-3), 207-212.

Gadhi, C. A., Weber, M., Mory, F., Benharref, A., Lion, C., Jana, M., \& Lozniewski, A. (1999). Antibacterial activity of Aristolochia paucinervis Pomel. Journal of ethnopharmacology, 67(1), 87-92.

Hong, C. H., Hur, S. K., Oh, O. J., Kim, S. S., Nam, K. A., \& Lee, S. K. (2002). Evaluation of natural products on inhibition of inducible cyclooxygenase (COX-2) and nitric oxide synthase (iNOS) in cultured mouse macrophage cells. Journal of Ethnopharmacology, 83(1-2), 153-159.

Kumar, V., Prasad, A. K., \& Parmar, V. S. (2003). Naturally occurring aristolactams, aristolochic acids and dioxoaporphines and their biological activities. Natural product reports, 20(6), 565-583.

Liu, M. C., Lin, T. H., Wu, T. S., Yu, F. Y., Lu, C. C., \& Liu, B. H. (2011). Aristolochic acid I suppressed inos gene expression and NF- $\mathrm{BB}$ activation in stimulated macrophage cells. Toxicology letters, 202(2), 93-99.

Liu, Y. Z., Cao, Y. G., Ye, J. Q., Wang, W. G., Song, K. J., Wang, X. L., .. \& Deng, X. M. (2010). Immunomodulatory effects of proanthocyanidin A-1 derived in vitro from Rhododendron spiciferum. Fitoterapia, 81(2), 108-114.
Lord, G. M., Cook, T., Arit, V. M., Schmeiser, H. H., Williams, G., \& Pusey, C. D. (2001). Urothelial malignant disease and Chinese herbal nephropathy. The Lancet, 358(9292), 1515-1516.

Merzouki, A., Ed-Derfoufi, F., El Aallali, A., \& MoleroMesa, J. (1997). Wild medicinal plants used by local Bouhmed population (Morocco). Fitoterapia (Milano), 68(5), 444-460.

Miller, L. C., \& Tainter, M. L. (1944). Evalution of LD50 and its error by means of logarithmic probit graph papers. Proc Soc Exp Biol Med, 57, 26.

Mosdam, T. (1983). Rapid colorimetric assay for cellular growth and survival: application to proliferation and cytotoxic assay. J. Immunol. Methods, 65, 55-63.

Ngoupayo, J., Tabopda, T. K., \& Ali, M. S. (2009). Antimicrobial and immunomodulatory properties of prenylated xanthones from twigs of Garcinia staudtii. Bioorganic \& medicinal chemistry, 17(15), 5688-5695.

Raisuddin, S., Zaidi, S. I. A., Singh, K. P., \& Ray, P. K. (1991). Effect of subchronic aflatoxin exposure on growth and progression of Ehrlich's ascites tumor in mice. Drug and chemical toxicology, 14(1-2), 185-206.

Seongeun, C, Andrew W. and Mark, R. (2007). Brain slices as models for neurodegenerative disease and screening platforms to identify novel therapeutics. Curr. Neuropharmacol, 5; (19-33).

Wising, C, Azem, J., Zetterberg, M., Svensson, L. A., Ahlman, K., \& Lagergård, T. (2005). Induction of apoptosis/necrosis in various human cell lineages by Haemophilus ducreyi cytolethal distending toxin. Toxicon, 45(6), 767-776.

Wu, T. S., Damu, A. G., Su, C. R., \& Kuo, P. C. (2004). Terpenoids of Aristolochia and their biological activities. Natural Product Reports, 21(5), 594-624.

Yadav, R, Kharya, D. M. Yadav N. and Savadi, R. (2011). Immunomodulatory potential of ethanol extract of Spilanthus acmella leaves. Int. J. Biol. Med. Res, 2; (631-635). 